\title{
HUMAN EXPOSURE TO CYANOTOXINS AND THEIR EFFECTS ON HEALTH
}

\author{
Damjana DROBAC ${ }^{1}$, Nada TOKODI ${ }^{1}$, Jelica SIMEUNOVIĆ ${ }^{1}$, Vladimir BALTIĆ ${ }^{2}$, Dina STANIĆ ${ }^{3}$, \\ and Zorica SVIRČEV ${ }^{1}$
}

Department of Biology and Ecology, Faculty of Sciences, University of Novi Sad, Novi Sad', Oncology Institute of Vojvodina, Sremska Kamenica ${ }^{2}$ Serbia, Department of Biological Sciences, Florida International University, Miami, FL, USA

Received in October 2012

CrossChecked in March 2013

Accepted in February 2013

\begin{abstract}
Cyanotoxins are secondary metabolites produced by cyanobacteria. They pose a threat to human health and the environment. This review summarises the existing data on human exposure to cyanotoxins through drinking water, recreational activities (e.g., swimming, canoeing or bathing), the aquatic food web, terrestrial plants, food supplements, and haemodialysis. Furthermore, it discusses the tolerable daily intake and guideline values for cyanotoxins (especially microcystins) as well as the need to implement risk management measures via national and international legislation.
\end{abstract}

KEY WORDS: aquatic animals, cyanobacterial blooms, dietary supplements, haemodialysis, microcystins

Cyanobacteria, also known as blue green algae, are present in many water ecosystems. Their increased growth is referred to as cyanobacterial bloom (1). Large cyanobacterial blooms are classified as "harmful" when they lead to negative environmental impacts such as mortality, ecosystem instability, and the production of highly active toxic compounds known as cyanotoxins (2). Cyanotoxins are diverse in chemical structure and toxicity. Depending on the human organ affected, cyanotoxins are classified as hepatotoxins (microcystins, nodularin, cylindrospermopsin), neurotoxins (saxitoxins, anatoxin-a, anatoxin-a(s), homoanatoxin-a), cytotoxins (aplysiatoxin, debromoaplysiatoxin, lingbyatoxin, lipopolysaharide endotoxin), and skin and gastrointestinal irritants $(3,4)$. The most common cyanotoxin group are microcystins (MCs) (1), while microcystin-LR (MC-LR) is their most toxic structural variant (5). Toxic cyanobacteria and their toxic metabolites pose a health hazard to plants and animals
$(6,7)$. These toxins can also cause illnesses in humans $(8,9)$, or even death when one is exposed through haemodialysis (10). Following exposure to cyanotoxins, symptoms such as abdominal pain, vomiting, diarrhoea, skin irritation, weakness, sore throat, pale mucous membrane, and muscle tremors were observed in animals and humans (1). MCs require additional attention, not only for their ability to cause acute poisoning, but also for their ability to initiate cancer through acute doses and potentially promote it through chronic exposure to low MC concentrations in drinking water $(9,11,12)$. In 2006 in Lyon, France, the International Agency for Research on Cancer (IARC), performed an assessment of the cancerogenesis of MC-LR and concluded that MC-LR is a possible carcinogen for humans, classifying it as a group $2 \mathrm{~B}$ carcinogen (13). The health threats caused by cyanotoxins, especially MCs, have led the World Health Organization (WHO) to establish a tolerable daily intake (TDI) $\left(0.04 \mu \mathrm{g} \mathrm{kg}^{-1}\right)$ and a provisional 
guideline value for MC-LR in drinking water $\left(1 \mu \mathrm{g} \mathrm{L}^{-1}\right)$ (14). Also, guidance values for other exposure pathways such as recreational water, food, and supplements, were established (15). Some countries accepted the stated values (the Czech Republic, France, Japan, Korea, New Zealand, Norway, Poland, Brazil, and Spain), while others formulated their own values, depending on the local conditions (Australia, Canada). The most pervasive legislation was introduced in Brazil, setting the mandatory standard to $1 \mu \mathrm{g} \mathrm{L}^{-1}$ for MCs, and the recommended values for saxitoxins and cylindrospermopsin to $3 \mu \mathrm{g} \mathrm{L}^{-1}$ and $15 \mu \mathrm{g} \mathrm{L}^{-1}$, respectively (16).

This review focuses on the cyanobacterial toxicity and cyanotoxin accumulation in various aquatic organisms, edible plants, dietary supplements, and drinking water supplies as probable pathways for toxins to reach humans. A possible derivation and implementation of guideline values for these cyanotoxins is also discussed.

\section{Routes of exposure}

The major routes of human exposure to cyanotoxins are: chronic and accidental ingestion of contaminated drinking water; inhalation or contact with the nasal mucous membrane, and dermal contact with toxins during recreational activities such as swimming, canoeing or bathing; consumption of contaminated vegetables and fruits irrigated with water containing cyanotoxins; consumption of aquatic organisms (fish, shellfish, etc.) from contaminated waters; oral intake of cyanobacterial dietary supplements (if cyanotoxin levels are not controlled); and the specific intravenous route caused by dialysis.

\section{Ingestion of contaminated drinking water}

Direct ingestion of contaminated drinking water is a frequent route of cyanotoxin intake. If the water is obtained from a surface water source during cyanobacterial bloom, it is possible that the water had become contaminated with toxins released during cell decomposition (1). There are numerous cases of cyanobacterial toxins detected in raw and final water throughout the world (Argentina, Australia, Bangladesh, Canada, Czech Republic, China, Finland, France, Germany, Latvia, Poland, Thailand, Turkey, Spain, Switzerland, USA) (15, 17-19). High levels of risk to human health are linked to the ingestion of large cyanotoxin quantities from water or the intake of small doses during extended chronic exposure (20).
Hepatotoxins in drinking water could be a risk factor for primary liver cancer (PLC), but only a limited number of epidemiological studies have confronted this issue. The prevailing opinion in the literature is that the development of PLC results from cirrhosis and chronic viral hepatitis (HBV and HCV). However, this could not be concluded from the obtained data on the incidence of PLC, HBV, HCV, and liver cirrhosis mortality in central Serbia from 2000 to 2006; no correlation between PLC and these diseases was found (21). On the other hand, epidemiological studies in Serbia have shown that the consumption of drinking water contaminated by MCs could be connected to human PLC $(9,20,22)$. Similarly, a relationship between an increased risk of PLC and the quality of surface water was detected by Fleming et al. (23) in Florida. This kind of analysis was also conducted in China, where some authors (24) suggested that hepatotoxins from water reservoirs containing cyanobacteria triggered the development of PLC. Based on these reports, MCs could be an important chemical and external factor in the development of PLC.

\section{Dermal contact and exposure through inhalation}

Dermal contact occurs in recreational waters which endure the presence of cyanobacterial blooms. A wide range of symptoms associated with recreational exposure to cyanobacteria have been described: desquamation, skin rashes, asthma, pneumonia, dry sporadic cough with vomiting and other gastrointestinal symptoms, hay fever, conjunctivitis, ear and eye irritation, allergic reactions, and acute illnesses with symptoms such as severe headache, myalgia, vertigo, and blistering in the mouth. These symptoms were reported in the coastal waters of Japan, Hawaii, Australia, and Florida (25-28). Freshwater cyanobacterial blooms have also caused similar symptoms after swimming or water contact sports (29).

The cyanobacterial mats that form on the surface of coastal waters get broken apart by waves. Persons swimming in the affected waters collect cyanobacterial filaments under their bathing suits. The cells that accumulate under the fabric may come in contact with the skin and lead to skin irritation (30). "Swimmer's itch" is a severe contact dermatitis which occurs after swimming in marine waters that contain specific cyanobacterial blooms (e.g., Lyngbia majuscula). Within a period ranging from a few minutes to a few hours, itching and burning occurs. Visible dermatitis 
and redness develop after tree to eight hours, followed by blisters and deep desquamation (31).

During recreation, one potential exposure route is inhalation. Respiratory distress has been reported after exposure to certain marine and freshwater blooms $(7,32,33)$. Intranasal administration of MC-LR to mice has led to liver damage and extensive necrosis of the olfactory and respiratory zone epithelium. Moreover, the sensitivity was approximately 10 times greater than through oral exposure (34). Therefore, potential exposure to cyanotoxins through inhalation should not be ignored during showering, water sports (particularly water-skiing), and work practices involving agricultural or industrial spray water (29).

Also, cyanobacteria are vital primary producers in desert environments. Samples from dry, ephemeral river beds, and supertidal salt flats in Qatar were analysed for cyanotoxins. Based on the level of MCs detected in the crust of all samples (at mass fractions between $1.5 \mathrm{ng} \mathrm{g}^{-1}$ and $53.7 \mathrm{ng} \mathrm{g}^{-1}$ ), the amount of dust inhaled by a person could have surpassed the TDI value of $1 \mathrm{ng}$ to $2 \mathrm{ng}$ of MCs per kilogram per day for an average adult. The presence of MCs, and potentially anatoxin-a(s), in desert crusts has substantial implications for the human health (35).

\section{Terrestrial and aquatic plants}

Crops can come into contact with cyanotoxins when surface water bodies containing cyanobacteria are used for spray irrigation or watering. Consequently, both plant yield and quality are affected. Furthermore, if the MC absorption exceeds the recommended tolerable limits, the affected plant might pose a risk for human and animal health (36).

Previous research has revealed that cyanotoxins can have negative effects on plants (37-40). Seedling exposure to cyanotoxins can cause growth inhibitions in a variety of terrestrial plants (41-44). The growth, development, photosynthetic activity, productivity, and mineral nutrition of wheat (Triticum durum), maize (Zea mays), pea (Pisum sativum), and lentil (Lens esculenta) cultivars was also found to be diversely affected by a cyanobacterial extract with MC-LR (36). It was also noted that, both submerged and emergent, aquatic plants absorb MC-LR from low external concentrations, and accumulate it in the shoot tissue $(39,45,46)$. Furthermore, when exposed to MC-LR, aquatic plants exhibited an inhibition of growth and photosynthetic oxygen production, while their chlorophyll pigments became bleached (47).
Previous studies have shown that MC can be detected in the tissues of exposed terrestrial and aquatic plants $(38,40,42,43,45,48-50)$. Based on the results of a glasshouse experiment, when a $60 \mathrm{~kg}$ individual consumes $65 \mathrm{~g}$ to $75 \mathrm{~g}$ of fresh weight salad (6.8 $\mathrm{g}$ to $7.9 \mathrm{~g}$ dry weight), made with lettuce irrigated by lake water containing MCs, he/she also ingests approximately $5.8 \mu \mathrm{g}$ of MCs per meal $\left(0.10 \mu \mathrm{g} \mathrm{kg}^{-1}\right.$ of body weight). This level is above the provisional WHO TDI of $0.04 \mu \mathrm{g} \mathrm{kg}^{-1}$ b.w. per day for MC-LR consumed throughout a lifetime (51). One study confirmed that shoot cultures of apple (Malus pumila) accumulated an $\mathrm{MC}$ concentration of as much as $(510.23 \pm 141.10)$ ng equivalents of MC-LR per gram of fresh weight after 14 days of exposure to $3 \mu \mathrm{g} \mathrm{mL}^{-1}$ of MCs (52). Peuthert et al. (53) documented the uptake of MC-LR and MC-LF by the seedling roots of 11 agricultural plants, along with their ability to translocate them to the shoots. The MCs recovered from the exposed plants suggested that, when MCcontaining water is used for irrigation, terrestrial plants exhibit toxic effects on the human health (52).

In rice fields, cyanobacteria can fixate nitrogen from the atmosphere and provide an important nitrogen source for rice plants (54). However, the MC uptake mechanisms of rice plants are not yet fully understood, which makes it hard to grasp the full impact of cyanotoxin exposure on human health.

\section{Cyanobacterial toxicity through the aquatic food web}

The bioaccumulation of cyanotoxins can occur in a wide range of aquatic animals used for human consumption. MCs were detected in freshwater shrimps (Palemon modestus, Macrobrachium nipponensis), and red swamp crayfish (Procamburus clarkii) $(55,56)$, while in the marine environment, saxitoxins were detected in pearl oysters (Pinctada maxima) (57). Also, cylindrospermopsin was found in bivalve hemolymphs, viscera, gonads, and feet (58). Saxitoxins from the Anabaena circinalis species can accumulate in Australian freshwater mussels after only one week of exposure to a cell density of 100,000 cells per millilitre, which usually occurs during this species' bloom (59). Furthermore, MC was detected in the hepatopancreas, viscera, gonad, gill, and foot of the freshwater snail Bellamya aeruginosa (60). Chen et al. (60) found that most toxins are located in the inedible parts, which means that removing the hepatopancreas, digestive tract, and gonads before consumption could decrease the risk of intoxication. 
However, since for instance snails are usually boiled whole, this creates a pathway for the ingestion of MCs. Furthermore, it should be noted that boiling does not destroy most of the known cyanobacterial toxins (15). White et al. (61) found cylindrospermopsin in another freshwater snail species (Melanoides tuberculata), generally not used in the human diet. Nonetheless, the aquatic food chain and bioaccumulation enables cyanotoxins to ultimately reach humans.

Being at the very top of the aquatic food chain, fish are probably the most exposed to cyanotoxins, which may accumulate in the liver, muscles, gills, guts, and kidneys (62). Fish are exposed through feeding or breathing (63). MCs are actively taken up by the liver, disrupting normal cellular activity by inhibiting protein phosphatases $(64,65)$, which are particularly important during fish embryogenesis, since they regulate critical developmental processes (66).

In early stages of life, exposure to MCs can disrupt normal embryonic hatching, decrease the survival and growth rate, and cause certain histopathological effects (enlarged and opaque yolk sac, small head, curved body and tail, hepatobiliary abnormalities, ultrastructural alterations in hepatocytes, heart rate perturbations). In adults and juveniles, MC exposure can influence the growth rate and osmoregulation, increase the heart rate and liver enzyme activity in the serum, alter behaviour, and cause histopathological changes in the liver, intestines, kidneys, heart, spleen, or gills. These abnormalities vary depending on the cyanotoxin dose and exposure routes (63). When exposed to a lower MC concentration $\left(10 \mu \mathrm{g} \mathrm{L}^{-1}\right.$ and $\left.100 \mu \mathrm{g} \mathrm{L}^{-1}\right)$, carp hepatocytes died through apoptosis, whereas when a higher one was applied $\left(1000 \mu \mathrm{g} \mathrm{L}^{-1}\right)$, they died through necrosis (67). Histopathological analysis showed that cyanobacterial toxins are capable of killing fish (68).

Furthermore, it was observed that MCs primarily accumulate in fish livers, but can also be detected in muscles and viscera (63). MC concentrations are often highest in the gut and liver, lower in kidneys and gonads, and the lowest in muscle tissue (69-71). Romo et al. (72) investigated toxin accumulation in the fish tissues of the commercial species Liza sp. They found high $\mathrm{MC}$ concentrations in the liver, intestines, gills and muscles. Moreover, the mean MC concentration in the muscles corresponded to a daily intake of $0.025 \mu \mathrm{g} \mathrm{kg}^{-1}$, while $13 \%$ of the analysed specimens had values above the recommended guideline concentration. On average, 200 tons of Liza sp. is sold each year, which is, based on the mean $\mathrm{MC}$ value in this study, equivalent to nearly $350 \mathrm{mg}$ of MCs (5 ng $\mathrm{g}^{-1}$ fish muscle). This amount is potentially even greater if we consider that birds and other animals feed on fish (72). However, new studies have shown that MC biodilution is the prevailing process in aquatic food webs, consistent across groups of aquatic consumers with the exception of zooplankton and zooplanktivorous fish (73). Still, more thorough research is needed on this subject.

Cyanotoxin accumulation in fish tissue may pose a risk to human health. The risks associated with consuming aquatic products were evaluated by analysing 26 of the most frequently consumed fish and shellfish species from three large lakes in China. The results indicated that most of the aquatic products from these lakes seemed to have been unsafe for human consumption due to $\mathrm{MC}$ accumulation, with the estimated daily intake values being 1.5 to 148 times higher than the TDI (74). The distribution and bioaccumulation of MCs in Carassius gibelio was surveyed in 13 Greek lakes. MCs were found in livers, intestines, kidneys, brains, ovaries, and muscles. MC average values in fish muscles were $(7.1 \pm 2.5) \mathrm{ng} \mathrm{g}^{-1}$, while the concentrations found in several lakes exceeded the WHO TDI. According to the authors, a healthy $60 \mathrm{~kg}$ person who consumed a $300 \mathrm{~g}$ serving of $C$. gibelio on average daily would be at risk, even more so in the case of the elderly, children, or sensitive individuals (75).

The Wild Nile and redbreast tilapia (Oreochromis niloticus and Tilapia rendalli) were sampled at the Brazilian eutrophic stations of the Funil and Furnas reservoirs. All of the sampled fish contained MCs (from $0.8 \mu \mathrm{g} \mathrm{g}^{-1}$ to $32.1 \mu \mathrm{g} \mathrm{g}^{-1}$ liver; from $0.9 \mathrm{ng} \mathrm{g}^{-1}$ to $12.0 \mathrm{ng} \mathrm{g}^{-1}$ muscle). Among the 27 fish examined at both reservoirs, $26 \%$ (all $O$. Niloticus) were above the WHO TDI. Furthermore, even though the MC concentrations ( $986 \mathrm{ng} \mathrm{L}^{-1}$ at the Funil and $941 \mathrm{ng} \mathrm{L}^{-1}$ at the Furnas reservoir) were below the WHO guideline for drinking water, the MCs in the fish had accumulated to toxic levels (76).

It has also been found that different species of fish accumulate different amounts of MCs. One study found the MC content in the liver and muscle to be highest in carnivorous fish, followed by omnivorous fish, while the lowest was in phytoplanktivorous and herbivorous fish. MCs can therefore accumulate upwardly in the food chain (71). In another study, MCs in the livers and guts were highest in phytoplanktivorous fish, followed by omnivorous and 
carnivorous fish. On the other hand, MCs in muscles were highest in omnivorous fish, then phytoplanktivorous, and finally in carnivorous fish (77). It is obvious that the feeding style of a fish and the cyanotoxin accumulation in its tissue still cannot be clearly interrelated (78).

An investigation of cylindrospermopsin bioaccumulation in the muscle tissue of the redclaw crayfish (Cherax quadricarinatus) and the visceral tissues of the rainbow fish (Melanotaenia eachamensis) showed that exposure to this toxin may occur in aquaculture ponds (79). The accumulation of saxitoxins was investigated by monitoring cyanotoxin levels in the liver and muscle samples of Oreochromis niloticus, showing that the Wild Nile tilapia is capable of bioaccumulating saxitoxins (80). A recent study at Lake Catemaco (Veracruz, Mexico), a lake with extensive Cylindrospermopsis blooms throughout the year, showed a presence of cylindrospermopsin and saxitoxins in finfish species used for local consumption, and also indicated possible bioaccumulation (81). Due to this potential presence of cyanotoxins in edible aquatic organisms, toxic cyanobacteria blooms in aquacultures could pose a risk to fish quality and, consequently, affect public health. Recently, a more comprehensive review was published on this topic (82).

\section{Cyanobacterial dietary supplements}

Cyanobacteria intake can also be voluntary, mostly for its rich protein content (e.g., Spirulina, Nostoc, and Aphanizomenon flos-aquae). Blue green algae supplements (BGAS) are mainly sold in industrialised countries, due to their beneficial health effects such as detoxification, weight loss, elevated mood and energy, and increased alertness $(83,84)$. Furthermore, some of these products are used in the pharmacological therapy of Attention Deficit Hyperactivity Disorder in children (85).

These products come in the form of pills, capsules, and powders, and can be consumed without any medical consultation. Since these products are natural, it is assumed that they are safe, and therefore BGAS may be taken at high doses and over a long period of time. However, they can have negative health effects, including symptoms such as nausea, vomiting, and diarrhoea. Although gastro-intestinal disturbance can be associated with BGAS consumption, it is usually attributed to the "detoxification" of the body. Also, certain potentially adverse effects can go unrecognized, while in many cases, the causative agent(s) and toxicity mechanisms are unclear (86).

However, traces of cyanotoxins have been found in BGAS products. Despite the general opinion that Spirulina is not toxic, epoxyanatoxin-a and dihydrohomoanatoxin-a have been identified in a Spirulina-based BGAS (87). Also, it was found that Spirulina fusiformis can produce low concentrations of MCs and anatoxin-a $(88,89)$. In addition, the Spirulina-based BGAS was suspected to cause liver damage in a middle-aged Japanese person (90). The Aph. flos-aquae species was found to produce anatoxin-a (91) and saxitoxins $(92,93)$, as well as BMAA ( $\beta$-Methylamino Alanine) (94). A. flos-aquae is generally harvested from natural lakes, where it coexists with other cyanobacterial species such as Microcystis sp. (83), which implies that BGAS consumers may be exposed to MCs and other toxins.

Several independent investigations reported high MC levels in BGAS products (95-98), sometimes even higher than the provisional guidance value of $1 \mu \mathrm{g} \mathrm{g}^{-1} \mathrm{~d}$. w. set by the Oregon Health Division and Oregon Department of Agriculture (86). In studies from 2000 and 2001, before awareness generally increased and regulations started being implemented, $\mathrm{MC}$ levels in BGAS products reached as much as $35 \mu \mathrm{g} \mathrm{g}^{-1}$ d.w. (86, 95). In the German and Swiss markets, 8 out of 13 BGAS products exceeded $1.0 \mu \mathrm{g}$ equiv of MC-LR per gram d.w. (97). However, it is important to stress that not all BGAS products contain high MC concentrations, and that certain brands are known to have different $\mathrm{MC}$ concentrations from batch to batch $(86,97)$.

The Oregon provisional tolerable level for MCs in BGAS $\left(1.0 \mu \mathrm{g} \mathrm{g}^{-1}\right.$ MC-LR of dry weight) was calculated for adults, which means that children could be even more susceptible to MCs. Apart from the body weight of a consumer, guidance values for MC-LR are also influenced by the daily amount of BGAS consumed, which largely depends on the individual, and can range from $0.25 \mathrm{~g}$ to $20 \mathrm{~g}(86,99)$. Therefore, a daily consumption of several grams, which may contain from $1 \mu \mathrm{g}$ equivalent to $35 \mu \mathrm{g}$ equivalent MC-LR per gram of dry weight (96), could exceed the TDI and lead to long-term health problems. However, these could be avoided with more frequent control of BGAS products for cyanotoxin contamination and a decrease in the present guidance values. Based on these data, BGAS products can pose a health threat to consumers, especially children, so this exposure 
pathway should receive more attention in future research.

\section{The intravenous route}

In 1996, an incident took place at the haemodialysis centre in Caruaru, Brazil. After a routine haemodialysis treatment, most patients (116 out of 131) experienced visual disturbances, nausea, vomiting, and muscle weakness. After a period of time, one hundred patients developed acute liver failure, and the "Caruaru Syndrome" lead to 52 fatalities. MCs were detected in all of the patient serum and liver tissue samples, while cylindrospermopsin was found in the carbon and resins from the clinic's water treatment system. Moreover, cyanobacteria had a powerful presence in the local water reservoirs. Finally, it was concluded that the main contributing factor to the death of these patients was intravenous exposure to MCs (MC-YR, MC-LR and MC-AR). In 2000, cyanobacteria and cyanotoxins were incorporated into Brazilian legislation regarding the quality of drinking water (100).

\section{DISCUSSION}

For certain critical routes of exposure, the WHO and certain other institutions provided guideline values for MC-LR based on the tolerable daily intake. The TDI is the amount of a potentially harmful substance that can be consumed daily over a lifetime with negligible risk of adverse health effects. The guideline value for MC-LR was derived from a 13-week mouse oral study with pure MC-LR. Based on the liver histopathology and serum enzyme level changes, a NOAEL (no-observed adverse effect level) of $40 \mu \mathrm{g} \mathrm{kg}^{-1}$ b.w. per day was determined (101). By applying a total uncertainty factor of 1000 (10 for intra-species variability, 10 for inter-species variability and 10 for limitations in the database), a provisional TDI of $0.04 \mu \mathrm{g} \mathrm{kg}^{-1}$ b.w. per day was calculated for MC-LR. Then, a proportion of the total intake from various sources of exposure (e.g., drinking water, food, etc.), often termed allocation factors, was multiplied by the body weight of a standardized adult $(60 \mathrm{~kg}$ or $70 \mathrm{~kg}$ ) and the TDI, and then divided by the daily intake of the source (e.g., $2 \mathrm{~L}$ drinking water, $0.1 \mathrm{~kg}$ fish, $2 \mathrm{~g}$ BGAS).

However, it would be advisable to revise the obtained guideline values. Although the main target for MCs is the liver, it can affect other organs, such as the colon $(11,102)$, intestines $(103)$, brain $(104$, 105), lungs (105, 106), heart (107), kidneys (108-110), and reproductive system $(111,112)$. Also, over 90 analogues of MCs have been identified (113) and found to be toxic, but are not presently monitored. Nonetheless, a given species of cyanobacteria can produce a variety of potent cyanotoxins, and for most of them, the TDI cannot be derived due to a lack of toxicological data. So far, research on cyanobacterial carcinogenicity and tumour promotion has mainly focused on hepatotoxins (e.g., MC, nodularin, and cylindrospermopsin). However, cyanobacteria could also produce other metabolites with potential tumourpromoting effects (114). Furthermore, a difference in the detected toxin concentration arises when diverse methods are applied. Current detection methods allow only the estimation of cyanotoxin concentrations due to their various limitations (e.g., sensitivity/selectivity), while most methods only measure free MCs (MCs that are not covalently-bound). Therefore, more precise and more reliable detection methods are necessary to derive adequate guideline values (15).

The level of risk to the human health depends on the cyanotoxin levels and exposure pathways. In a recent study, MCs were detected in the serum samples (average $0.39 \mathrm{ng} \mathrm{mL}^{-1}$ ) of fishermen from Lake Chaohu (China). The randomly chosen fisherman (14 male and 21 female) lived on the lake from 5 to over 10 years. During this period of time, they drank water from the lake and ate mostly aquatic products (fish, shrimp, and snails). The daily intake by the fishermen was estimated to be within the range from $2.2 \mu \mathrm{g}$ to $3.9 \mu \mathrm{g}$ MC-LReq, whereas the provisional WHO TDI for a daily lifetime exposure is $2 \mu \mathrm{g}$ to $3 \mu \mathrm{g}$ per person (115). The aforementioned data bring to question if extended exposure within the range of the TDI may still present a health risk.

Bearing in mind the possible chronic processes of accumulation in the human body, another issue should not be neglected: What kind of consequences does long-term exposure through different routes (drinking water, soup, fish soup, fish meat and seafood, supplements, consumption of vegetables after irrigation, recreational water activities, showering, etc.) have on the human health when cyanotoxin levels are elevated or even within the tolerable range? To prevent any potential risks, guideline values for cyanotoxins should be reviewed in light of more recent publications, particularly on potential exposure through food, and implemented into national 
regulations taking local exposure patterns into account. Also, it is recommended to improve sample preparation and detection methods for cyanotoxins, as well as the continuous monitoring of water, food, and BGAS products. But most importantly, it is necessary to control eutrophication, and subsequently reduce cyanobacterial growth and exposure to cyanotoxins.

\section{CONCLUSION}

This review has shown that humans can be exposed to cyanotoxins through various routes. The accumulation of cyanotoxins, particularly MCs, in some aquatic animals, edible plants, and dietary supplements raised awareness about the importance of food as an exposure route by which MCs can enter the human body. The precise doses of these toxins are still an open issue which should be solved in order to prevent possible health risks. Therefore, the formulation and implementation of risk management measures via national and international legislation is necessary to preserve aquatic environments as well as the human health.

\section{Acknowledgements}

This work was supported by the Ministry of Education and Science of the Republic of Serbia (Project number 176020).

\section{REFERENCES}

1. Chorus I, Bartram J. Toxic Cyanobacteria in Water: A Guide to Their Public Health Consequences, Monitoring, and Management. London: E\&FN Spon; 1999.

2. Chorus I. Cyanotoxins - Occurrence, Causes, Consequences Berlin: Springer-Verlag; 2001.

3. Kaebernick M, Neilan BA. Ecological and molecular investigations of cyanotoxin production. FEMS Microbiol Ecol 2001;35:1-9.

4. Briand JF, Jacket S, Bernard C, Humbert JF. Health hazards for terrestrial vertebrates from toxic cyanobacteria in surface water ecosystems. Vet Res 2003;34:361-77. doi: 10.1051/ vetres:2003019

5. Fitzgerald JD. Cyanotoxins and human health - overview. In: Chorus I, editor. Cyanotoxins: occurrence, causes, consequences. Berlin: Springer-Verlag; 2001. p. 179-90.

6. Carmichael WW, Falconer IR. Diseases related to freshwater blue-green algal toxins, and control measures. In: Falconer IR, editor. Algal toxins in seafood and drinking water London: Academic Press; 1993. p. 187-209.
7. Falconer IR. Algal toxins and human health. In: Hrubec J, editor. Handbook of environmental chemistry. Vol. 5, part C. Berlin: Springer-Verlag; 1998. p. 53-82.

8. Kuiper-Goodman T, Falconer IR, Fitzgerald J. Human health aspects. In: Chorus I, Bartram J, editors. Toxic cyanobacteria in water. A guide to their public health consequences, monitoring and management. London: E\&FN Spon; 1999. p. 113-53.

9. Svirčev Z, Krstić S, Miladinov-Mikov M, Baltić V, Vidović M. Freshwater cyanobacterial blooms and primary liver cancer epidemiological studies in Serbia. J Environ Sci Health C Environ Carcinog Ecotoxicol Rev 2009;27:36-55. doi: 10.1080/10590500802668016

10. Jochimsen EM, Carmichael WW, An JS, Cardo DM, Cookson ST, Holmes CE, Antunes MB, de Melo Filho DA, Lyra TM, Barreto VS, Azevedo SM, Jarvis WR. Liver failure and death after exposure to microcystins at a hemodialysis center in Brazil. N Engl J Med 1998;338:873-8.

11. Zhou L, Yu H, Chen K. Relationship between microcystin in drinking water and colorectal cancer. Biomed Environ Sci 2002;15:166-71.

12. Maatouk I, Bouaïcha N, Plessis MJ, Périn F. Detection by 32P-postlabeling detection of 8-oxo-7, 8-dihydro-20deoxyguanosine in DNA as biomarker of microcystin-LR and nodularin-induced DNA damages in vitro in primary cultured rat hepatocytes and in vivo in rat liver. Mutat Res 2004;564:9-20.

13. International Agency for Research on Cancer (IARC). Carcinogenicity of nitrate, nitrite, and cyanobacterial peptide toxins. Lancet Oncol 2006;7:628-9. doi: 10.1016/S14702045(06)70789-6

14. World Health Organization (WHO). Guidelines for drinkingwater quality. $2^{\text {nd }}$ ed. Addendum to Vol. 2. Geneva: WHO; 1998.

15. Dietrich D, Hoeger S. Guidance values for microcystins in water and cyanobacterial supplement products (blue-green algal supplements): a reasonable or misguided approach? Toxicol Appl Pharmacol 2005;203:273-89.

16. Burch MD. Effective doses, guidelines and regulations. Adv Exp Med Biol 2008;619:831-53. doi: 10.1007/978-0-38775865-7_36

17. Westrick JA. Everything a manager should know about algal toxins but was afraid to ask. JAWWA 2003;95:26-34.

18. Hoeger SJ, Shaw G, Hitzfeld BC, Dietrich DR. Occurrence and elimination of cyanobacterial toxins in two Australian drinking water treatment plants. Toxicon 2004;43:639-49. doi: 10.1016/j.toxicon.2004.02.019

19. Hoeger SJ, Hitzfeld BC, Dietrich DR. Occurrence and elimination of cyanobacterial toxins in drinking water treatment plants. Toxicol Appl Pharmacol 2005;203:23142.

20. Svirčev Z, Baltić V, Gantar M, Juković M, Stojanović D, Baltić M. Molecular Aspects of microcystin-induced hepatotoxicity and hepatocarcinogenesis. J Environ Sci Health C Environ Carcinog Ecotoxicol Rev 2010;28:39-59. doi: 10.1080/10590500903585382

21. Drobac D, Svirčev Z, Tokodi N, Vidović M, Baltić V, BožićKrstić V, Lazić D, Pavlica T. Microcystins - potential risk factors in carcinogenesis of primary liver cancer in Serbia. Geographica Pannonica 2011;15:70-80.

22. Svirčev Z, Simeunović J, Subakov-Simić G, Krstić S, Vidović M. Freshwater cyanobacterial blooms and cyanotoxin 
production in Serbia in the past 25 years. Geographica Pannonica 2007;11:12-21.

23. Fleming L, Rivero C, Burns J, Williams C, Beana J, Shea K, Stinn J. Bluegreen algal (cyanobacterial) toxins, surface drinking water, and liver cancer in Florida. Harmful Algae 2002;1:157-68

24. Yu SZ. Primary prevention of hepatocellular carcinoma. J Gastroenterol Hepatol 1995;10:674-82.

25. Grauer FH, Arnold HL. Seaweed dermatitis: first report of dermatitis-producing marine algae. Arch Dermatol $1961 ; 84: 720-32$. doi: 10.1001/archderm. 1961.01580170014003

26. Cardellina JH 2nd, Marner FJ, Moore RE. Seaweed dermatitis: structure of lyngbyatoxin A. Science 1979;204:193-5. doi: 10.1126/science. 107586

27. Yasumoto T, Murata M. Marine toxins. Chem Rev 1993;93:1897-909.

28. Stewart I, Webb PM, Schluter PJ, Shaw GR. Recreational and occupational field exposure to freshwater cyanobacteria - a review of anecdotal and case reports, epidemiological studies and the challenges for epidemiologic assessment. Environ Health 2006;5:6. doi: 10.1186/1476-069X-5-6

29. Codd GA, Bell S, Kaya K, Ward C, Beattie KA, Metcalf JS Cyanobacterial toxins, exposure routes and human health Eur J Phycol 1999; 34:405-15.

30. Burke WA, Tester PA. Skin problems related to noninfectious coastal microorganisms. Dermatol Ther 2002;15:10-7.

31. World Health Organization (WHO). Guidelines for Safe Recreational Water Environments. Vol 1: Coastal and fresh waters. Geneva: WHO; 2003.

32. Hawser SP, Codd GA, Capone DG, Carpenter EJ. A neurotoxic factor associated with the bloom-forming cyanobacterium Trichodesmium. Toxicon 1991;29:277-8.

33. Lyngbya Task Force (LTF). Factors Associated with the Proliferation of the Toxic Cyanobacterium Lyngbya majuscula in Coastal Waters of Queensland: Triggers, Ecophysiology and Toxicology, Executive Summary 1. Brisbane: University of Queensland; 1998.

34. Fitzgeorge RB, Clark SA, Keevil CW. Routes of intoxication. In: Codd GA, Jefferies TM, Keevil CW, Potter E, editors. Detection methods for cyanobacterial toxins. Cambridge: The Royal Society of Chemistry; 1994. p. 69-74.

35. Metcalf JS, Richer R, Cox PA, Codd GA. Cyanotoxins in desert environments may present a risk to human health. Sci Total Environ 2012;421-422:118-23. doi: 10.1016/j. scitotenv.2012.01.053

36. Saqrane S, Ouahid Y, El Ghazali I, Oudra B, Bouarab L, del Campo F. Physiological changes in Triticum durum, Zea mays, Pisum sativum and Lens esculenta cultivars, caused by irrigation with water contaminated with microcystins: A laboratory experimental approach. Toxicon 2009;53:786-96. doi: 10.1016/j.toxicon.2009.01.028

37. MacKintosh C, Beattie KA, Klumpp S, Cohen P, Codd GA Cyanobacterial microcystin-LR is a potent and specific inhibitor of protein phosphatases 1 and 2A from both mammals and higher plants. FEBS Lett 1990;264:187-92.

38. Abe T, Lawson T, Weyers JDB, Codd GA. Microcystin-LR inhibits photosynthesis of Phaseolus vulgaris primary leaves: implications for current spray irrigation practice. New Phytol 1996;133:651-8. doi: 10.1111/j.1469-8137.1996.tb01934.x

39. Pflugmacher S, Ame MV, Wiegand C, Steinberg CE. Cyanobacterial toxins and endotoxins their origin and their ecophysiolocical effects in aquatic organisms. Wasser Boden 2001;53:15-20.

40. Chen J, Song L, Dai J, Gan N, Liu Z. Effects of microcystins on the growth and the activity of superoxide dismutase and peroxidase of rape (Brassica napus L.) and rice (Oryza sativa L.). Toxicon 2004;43:393-400. doi: 10.1016/j. toxicon.2004.01.011

41. Kós P, Gorzó G, Surányi G, Borbély G. Simple and efficient method for isolation and measurement of cyanobacterial hepatotoxins by plant tests (Sinapis alba L.). Anal Biochem 1995;225:49-53. doi: 10.1006/abio.1995.1106

42. Kurki-Helasmo K, Meriluoto J. Microcystin uptake inhibits growth and protein phosphatase activity in mustard (Sinapis alba L.) seedlings. Toxicon 1998;36:1921-6. doi: 10.1016/ s0041-0101(98)00114-7

43. McElhiney J, Lawton LA, Leifert C. Investigations into the inhibitory effects of microcystins on plant growth, and the toxicity of plant tissues following exposure. Toxicon 2001;39:1411-20. doi: 10.1016/S0041-0101(01)00100-3

44. M-Hamvas M, Máthé C, Molnár E, Vasas G, Grigorszky I, Borbely G. Microcystin-LR alters the growth, anthocyanin content and single-stranded DNase enzyme activities in Sinapis alba L. seedlings. Aquat Toxicol 2003;62:1-9.

45. Pflugmacher S, Wiegand C, Beattie KA, Codd GA, Steinberg CEW. Uptake of the cyanobacterial hepatotoxin microcystinLR by aquatic macrophytes. J Appl Bot 1998;72:228-32.

46. Yin LY, Huang JQ, Huang WM, Li DH, Wang GH, Liu YD. Microcystin-RR-induced accumulation of reactive oxygen species and alteration of antioxidant systems in tobacco BY2 cells. Toxicon 2005;46:507-12. doi: 10.1016/j. toxicon.2005.06.015

47. Pflugmacher S. Possible allelopathic effects of cyanotoxins, with reference to microcystin-LR, in aquatic ecosystems. Environ Toxicol 2002;17:407-13. doi: 10.1002/tox.10071

48. Codd GA, Metcalf JS, Beattie KA. Retention of Microcystis aeruginosa and microcystin by salad lettuce (Lactuca sativa) after spray irrigation with water containing cyanobacteria. Toxicon 1999;37:1181-5.

49. Mitrović SM, Allis O, Furey A, James KJ. Bioaccumulation and harmful effects of microcystin-LR in the aquatic plants Lemna minor and Wolffia arrhiza and the filamentous alga Chladophora fracta. Ecotoxicol Environ Safe 2005;61:34552. doi: 10.1016/j.ecoenv.2004.11.003

50. Jarvenpaa S, Lundberg-Niinisto C, Spoof L, Sjovall O, Tyystjarvi E, Meriluoto J. Effects of microcystins on broccoli and mustard, and analysis of accumulated toxin by liquid chromatography-mass spectrometry. Toxicon 2007;49:86574. doi: 10.1016/j.toxicon.2006.12.008

51. Crush JR, Briggs LR, Sprosen JM, Nichols SN. Effect of irrigation with lake water containing microcystins on microcystin content and growth of ryegrass, clover, rape, and lettuce. Environ Toxicol 2008;23:246-52. doi: 10.1002/ tox.20331

52. Chen J, Dai J, Zhang H, Wang C, Zhou G, Han Z, Liu Z. Bioaccumulation of microcystin and its oxidative stress in the apple (Malus pumila). Ecotoxicology 2010;19:796-803. doi: 10.1007/s10646-009-0456-5

53. Peuthert A, Chakrabarti S, Pflugmacher S. Uptake of microcystins-LR and -LF (cyanobacterial toxins) in seedlings of several important agricultural plant species and the correlation with cellular damage (lipid peroxidation). Environ Toxicol 2007;22:436-42. 
54. Rahman M, Podder AK, van Hove C, Begum T, Heulin T, Hartmann A. Biological Nitrogen Fixation Associated with Rice Production. Dordrecht: Kluwer Academic Publisher; 1996.

55. Chen J, Xie P. Seasonal dynamics of the hepatotoxic microcystins in various organs of four freshwater bivalves from the large eutrophic lake Taihu of subtropical China and the risk for human consumption. Environ Toxicol 2005;20:57284. doi: $10.1002 /$ tox. 20146

56. Chen J, Xie P. Tissue distributions and seasonal dynamics of the hepatotoxic microcystins-LR and -RR in two freshwater shrimps, Palaemon modestus and Macrobrachium nipponensis, from a large shallow, eutrophic lake of the subtropical China. Toxicon 2005;45:615-25.

57. Negri AP, Bunter O, Jones B, Llewellyn L. Effects of the bloom forming alga Trichodesmium erythraeum on the pearl oyster Pinctada maxima. Aquaculture 2004;232:91-102. doi: 10.1016/S0044-8486(03)00487-3

58. Saker ML, Metcalf JS, Codd GA, Vasconcelos VM Accumulation and depuration of the cyanobacterial toxin cylindrospermopsin in the freshwater mussel Anodonta cygnea. Toxicon 2004;43:185-94. doi: 10.1016/j. toxicon.2003.11.022

59. Negri AP, Jones GJ. Bioaccumulation of paralytic shellfish poisoning (PSP) toxins from the cyanobacterium Anabaena circinalis by the freshwater mussel Alathyria condola. Toxicon 1995;33:667-78. doi: 10.1016/0041-0101(94)00180G

60. Chen J, Xie P, Guo LG, Zheng L, Ni LY. Tissue distributions and seasonal dynamics of the hepatotoxic microcystins-LR and -RR in a freshwater snail (Bellamya aeruginosa) from a large shallow, eutrophic lake of the subtropical China. Environ Pollut 2005;134:423-30.

61. White SH, Duivenvoorden LJ, Fabbro LD, Eaglesham GK Influence of intracellular toxin concentrations on cylindrospermopsin bioaccumulation in a freshwater gastropod (Melanoides tuberculata). Toxicon 2006;47:497509. doi: 10.1016/j.toxicon.2005.12.011

62. Magalhaes VF, Marinho MM, Domingos P, Oliveira AC, Costa SM, Azevdeo LO, Azevedo SMFO. Microcystins (cyanobacteria hepatotoxins) bioaccumulation in fish and crustaceans from Sepetiba Bay (Brasil, RJ). Toxicon 2003;42:289-95. doi: 10.1016/S0041-0101(03)00144-2

63. Malbrouck C, Kestemont P. Effects of microcystins on fish. Environ Toxicol Chem 2006;25:72-86.

64. Tencalla F, Dietrich D. Biochemical characterization of microcystin toxicity in rainbow trout (Oncorhynchus mykiss). Toxicon 1997;35:583-95. doi: .1016/S0041-0101(96)001535

65. Malbrouck C, Trausch G, Devos P, Kestemont P. Effect of microcystin-LR on protein phosphatase activity and glycogen content in isolated hepatocytes of fed and fasted juvenile goldfish Carassius auratus L. Toxicon 2004;44:927-32. doi: 10.1016/j.toxicon.2004.09.003

66. Götz J, Probst A, Mistl C, Nitsch RM, Ehler E. Distinct role of protein phosphatase $2 \mathrm{~A}$ subunit $\mathrm{C}$ [alpha] in the regulation of E-cadherin and [beta]-catenin during development. Mech Dev 2000;93:83-93.

67. Li XY, Wang J, Liang JB, Liu YD. Toxicity of microcystins in the isolated hepatocytes of common carp (Cyprinus carpio L.). Ecotoxicol Environ Saf 2007;67:447-51. doi: 10.1016/ j.ecoenv.2006.10.003
68. Palikova M, Navratil S, Tichy F, Sterba F, Marsalek B, Blaha L. Histopathology of carp (Cyprinus carpio L.) larvae exposed to cyanobacteria extract. Acta Vet Brno 2004;73:2537. doi:10.2754/avb200473020253

69. Malbrouck C, Trausch G, Devos P, Kestemont P. Hepatic accumulation and effects of microcystin-LR on juvenile goldfish Carassius auratus L. Comp Biochem Physiol C Pharmacol Toxicol 2003;135:39-48.

70. Li XY, Chung IK, Kim JI, Lee JA. Subchronic oral toxicity of microcystin in common carp (Cyprinus carpio L.) exposed to Microcystis under laboratory conditions. Toxicon 2004;44:821-7. doi: 10.1016/j.toxicon.2004.06.010

71. Xie LQ, Xie P, Guo LG, Li L, Miyabara Y. Organ distribution and bioaccumulation of microcystins in freshwater fish at different trophic levels from the eutrophic Lake Chaohu, China. Environ Toxicol 2005;20:293-300.

72. Romo S, Fernández F, Ouahid Y, Barón-Sola A. Assessment of microcystins in lake water and fish (Mugilidae, Liza sp.) in the largest Spanish coastal lake. Environ Monit Assess 2012;184:939-49. doi: 10.1007/s10661-011-2011-0

73. Kozlowsky-Suzuki B, Wilson AE, Ferrao-Filho AS. Biomagnification or biodilution of microcystins in aquatic foodwebs? Meta-analyses of laboratory and field studies. Harmful Algae 2012;18:47-55. doi: 10.1016/j. hal.2012.04.002

74. Peng L, Liu Y, Chen W, Liu L, Kent M, Song L. Health risks associated with consumption of microcystin-contaminated fish and shellfish in three Chinese lakes: Significance for freshwater aquacultures. Ecotoxicol Environ Saf 2010;73:1804-11. doi: 10.1016/j.ecoenv.2010.07.043

75. Papadimitriou T, Kagalou I, Bacopoulos V, Leonardos ID. Accumulation of microcystins in water and fish tissues: an estimation of risks associated with microcystins in most of the Greek Lakes. Environ Toxicol 2010;25:418-27. doi: 10.1002/tox.20513

76. Deblois CP, Aranda-Rodriguez R, Giani A, Bird DF. Microcystin accumulation in liver and muscle of tilapia in two large Brazilian hydroelectric reservoirs. Toxicon 2008;51:435-48. doi: 10.1016/j.toxicon.2007.10.017

77. Zhang D, Xie P, Liu Y, Qiu T. Transfer, distribution and bioaccumulation of microcystins in the aquatic food web in Lake Taihu, China, with potential risks to human health. Sci Total Environ 2009;407:2191-9. doi: 10.1016/j. scitotenv.2008.12.039

78. Ibelings BW, Chorus I. Accumulation of cyanobacterial toxins in freshwater "seafood" and its consequences for public health: A review. Environ Pollut 2007;150:177-92.

79. Saker ML, Eaglesham GK. The accumulation of cylindrospermopsin from the cyanobacterium Cylindrospermopsis raciborskii in tissues of the redclaw crayfish Cherax quadricarinatus. Toxicon 1999;37:1065-77. doi: 10.1016/S0041-0101(98)00240-2

81. Galvão JA, Oetterer M, Bittencourt-Oliveira Mdo C, GouvêaBarros S, Hiller S, Erler K, Luckas B, Pinto E, Kujbida P. Saxitoxins accumulation by freshwater tilapia (Oreochromis niloticus) for human consumption. Toxicon 2009;54:891-4. doi: 10.1016/j.toxicon.2009.06.021

81. Berry JP, Jaja-Chimedza A, Dávalos-Lind L, Lind O. Apparent bioaccumulation of cylindrospermopsin and paralytic shellfish toxins by finfish in Lake Catemaco (Veracruz, Mexico). Food Addit Contam Part A Chem Anal 
Control Expo Risk Assess 2012;29:314-21. doi: 10.1080/19 440049.2011.597785

82. Ferrao-Filho AS, Kozlowsky-Suzuki B. Cyanotoxins: Bioaccumulation and effects on aquatic animals. Marine Drugs 2011;9:2729-72. doi:10.3390/md9122729

83. Carmichael WW, Drapeau C, Anderson DM. Harvesting of Aphanizomenon flos-aquae Ralfs ex Born. and Flah. var. flos-aquae (Cyanobacteria) from Klamath Lake for human dietary use. J Appl Phycol 2000;12:585-95.

84. Jensen GS, Ginsberg DI, Drapeau C. Blue-green algae as an immuno-enhancer and biomodulator. JANA 2001; 3:24-30.

85. Lindermann B. Complicated Child? Simple Options. Ramona (CA): Ransom Hill Press; 1995.

86. Gilroy DJ, Kauffman KW, Hall RA, Huang X, Chu FS. Assessing potential health risks from microcystin toxins in bluegreen algae dietary supplements. Environ Health Perspect 2000;108:435-9. doi:10.2307/3454384

87. Draisci R, Ferretti E, Palleschi L, Marchiafava C. Identification of anatoxins in blue-green algae food supplements using liquid chromatography-tandem mass spectrometry. Food Addit Contam 2001;18:525-31.

88. Ballot A, Krienitz L, Kotut K, Wiegand C, Metcalf JS, Codd GA, Pflugmacher S. Cyanobacteria and cyanobacterial toxins in three alkaline rift valley lakes of Kenya - Lakes Bogoria, Nakuru and Elmenteita. J Plankton Res 2004;26:925-35. doi: 10.1093/plankt/fbh084

89. Ballot A, Krienitz L, Kotut K, Wiegand C, Pflugmacher S. Cyanobacteria and cyanobacterial toxins in the alkaline crater lakes Sonachi and Simbi, Kenya. Harmful Algae 2005;4:13950. doi: 10.1016/j.hal.2004.01.001

90. Iwasa M, Yamamoto M, Tanaka Y, Kaito M, Adachi Y Spirulina-associated hepatotoxicity. Am J Gastroenterol 2002;97:3212-3. doi: 10.1111/j. 1572-0241.2002.07145.x

91. Rapala J, Sivonen K, Luukkainen R, Niemela SI. Anatoxina concentration in Anabaena and Aphanizomenon under different environmental conditions and comparison of growth by toxic and non-toxic Anabaena-strains: A laboratory study. J Appl Phycol 1993;5:581-91. doi: 10.1007/BF02184637

92. Pereira P, Onodera H, Andrinolo D, Franca S, Araujo F, Lagos N, Oshima Y. Paralytic shellfish toxins in the freshwater cyanobacterium Aphanizomenon flos-aquae, isolated from Montargil reservoir, Portugal. Toxicon 2000;38:1689-702. doi: /10.1016/S0041-0101(00)00100-8

93. Ferreira FMB, Soler JMF, Fidalgo ML, Fernandez-Vila P. PSP toxins from Aphanizomenon flos-aquae (cyanobacteria) collected in the Crestuma-Lever reservoir (Douro river, northern Portugal). Toxicon 2001;39:757-61. doi: 10.1016/ S0041-0101(00)00114-8

94. Cox PA, Banack SA, Murch SJ, Rasmussen U, Tien G, Bidigare RR, Metcalf JS, Morrison LF, Codd GA, Bergman B. Diverse taxa of cyanobacteria produce beta-Nmethylamino-L-alanine, a neurotoxic amino acid. Proc Nat Acad Sci USA 2005;102:5074-8.

95. Lawrence JF, Niedzwiadek B, Menard C, Lau BP, Lewis D, Kuiper- Goodman T, Carbone S, Holmes C. Comparison of liquid chromatography/mass spectrometry, ELISA, and phosphatase assay for the determination of microcystins in blue-green algae products. J AOAC Int 2001;84:1035-44.

96. Yu FY, Liu BH, Chou HN, Chu FS. Development of a sensitive ELISA for the determination of microcystins in algae. J Agric Food Chem 2002;50:4176-82. doi: 10.1021/ jf0202483
97. Hoeger SJ, Dietrich DR. Possible health risks arising from consumption of blue-green algae food supplements. Sixth International Conference on Toxic Cyanobacteria; 21-27 June 2004. Bergen, Norway. Abstract p. 30.

98. Saker ML, Jungblut AD, Neilan BA, Rawn DFK, Vasconcelos VM. Detection of microcystin synthetase genes in health food supplements containing the freshwater cyanobacterium Aphanizomenon flos-aquae. Toxicon 2005;46:555-62. doi: 10.1016/j.toxicon.2005.06.021

99. Schaeffer D, Malpas P, Barton L. Risk assessment of microcystin in dietary Aphanizomenon flos-aquae. Ecotoxicol Environ Saf 1999;44:73-80.

100. Azevedo SM, Carmichael WW, Jochimsen EM, Rinehart KL, Lau S, Shaw GR, Eaglesham GK. Human intoxication by microcystins during renal dialysis treatment in CaruaruBrazil. Toxicology 2002;181-182:441-6. doi: 10.1016/S0300483X(02)00491-2

101. Fawell J, James C, James H. Toxins from Blue-Green Algae: Toxicological Assessment of Microcystin-LR and a Method for Its Determination in Water. Marlow: Water Research Centre; 1994.

102. Humpage AR, Hardy SJ, Moore EJ, Froscio SM, Falconer IR. Microcystins (cyanobacterial toxins) in drinking water enhance the growth of aberrant crypt foci in the mouse colon. J Toxicol Environ Health A 2000;61:155-65.

103. Botha N, Van de Venter M, Downing TG, Shepard EG, Gehringer EG. The effect of intraperitoneally administered microcystin-LR on the gastrointestinal tract of $\mathrm{Balb} / \mathrm{c}$ mice. Toxicon 2004;43:251-4. doi: $10.1016 / \mathrm{j}$. toxicon.2003.11.026,

104. Maidana M, Carlis V, Galhardi FG, Yunes JS, Geracitano LA, Monserrat JM, Barros, DM. Effects of microcystins over short- and long-term memory and oxidative stress generation in hippocampus of rats. Chem Biol Interact 2006;159:2234

105. Žegura B, Volčič M, Lah TT, Filipič M. Different sensitivities of human colon adenocarcinoma ( $\mathrm{CaCo}-2)$, astrocytoma (IPDDC-A2) and lymphoblastoid (NCNC) cell lines to microcystin-LR induced reactive oxygen species and DNA damage. Toxicon 2008;52:518-25. doi: 10.1016/j. toxicon.2008.06.026

106. Soares RM, Cagido VR, Ferraro RB, Meyer-Fernandes JR, Rocco PRM, Zin WA, Azevedo SMFO. Effects of microcystin-LR on mouse lungs. Toxicon 2007;50:330-8. doi: 10.1016/j.toxicon.2007.04.003,

107. Milutinović A, Zorc-Pleskovič R, Petrovič D, Zorc M, Šuput D. Microcystin-LR induces alterations in heart muscle. Folia Biol (Praha) 2006;52:116-8.

108. Nobre ACL, Jorge MCM, Menezes DB, Fonteles MC, Monteiro HSA. Effects of microcystin-LR in isolated perfused rat kidney. Brazil J Med Biol Res 1999;32:985-8.

109. Milutinović A, Sedmak B, Horvat-Žnidaršić I, Šuput D. Renal injuries induced by chronic intoxication with microcystins. Cell Mol Biol Lett 2002;7:139-41.

110. Milutinović A, Živin M, Zorc-Plesković R, Sedmark B, Šuput D. Nephrotoxic effects of chronic administration of microcystins-LR and -YR. Toxicon 2003;42:281-8.

111. Ding XS, Li XY, Duan HY, Chung IK, Lee JA. Toxic effects of microcystis cell extracts on the reproductive system of male mice. Toxicon 2006;48:973-9. doi: 10.1016/j. toxicon.2006.07.039 
112. Li H, Xie P, Li G, Hao L, Xiong Q. In vivo study on the effects of microcystin extracts on the expression profiles of proto-oncogenes (c-fos, c-jun and c-myc) in liver, kidney and testis of male Wistar rats injected i.v. with toxins. Toxicon 2009;53:169-75. doi: 10.1016/j.toxicon.2008.10.027

113. Ufelmann H, Krüger T, Luckas B, Schrenk D. Human and rat hepatocyte toxicity and protein phosphatase 1 and $2 \mathrm{~A}$ inhibitory activity of naturally occurring desmethylmicrocystins and nodularins. Toxicology 2012;293:59-67. doi: 10.1016/j.tox.2011.12.011
114. Nováková K, Babica P, Adamovský O, Bláha L. Modulation of gap-junctional intercellular communication by series of cyanobacterial samples from nature and laboratory cultures. Toxicon 2011;58:76-84. doi: 10.1016/j. toxicon.2011.05.006

115. Chen J, Xie P, Li L, Xu J. First identification of the hepatotoxic microcystins in the serum of a chronically exposed human population together with indication of hepatocellular damage. Toxicol Sci 2009;108:81-9. doi: 10.1093/toxsci/kfp009 


\section{Sažetak}

\section{PUTEVI IZLOŽENOSTI LJUDI CIJANOTOKSINIMA I NJIHOVI UTJECAJI NA ZDRAVLJE}

Cijanotoksini su sekundarni metaboliti potencijalno opasni za ljudsko zdravlje i okoliš, koje proizvode cijanobakterije. Ovaj pregledni rad donosi prikaz postojećih podataka o izloženosti ljudi cijanotoksinima putem vode za piće, rekreacije, vodenog hranidbenog lanca, kopnenih biljaka i nekih drugih specifičnih puteva (dodaci prehrani i intravenozni put). Nadalje, u njemu se raspravlja o dopuštenom dnevnom unosu (TDI) i preporučenim vrijednostima za cijanotoksine (naročito mikrocistine) i nužnost provedbe mjera upravljanja rizicima putem nacionalnih i međunarodnih zakona. To su mjere od najveće važnosti za očuvanje okoliša i ljudskog zdravlja.

KLJUČNE RIJEČI: cvjetanje cijanobakterija, dodaci prehrani, hemodijaliza, mikrocistini, vodene životinje

\section{CORRESPONDING AUTHOR:}

Damjana Drobac

Department of Biology and Ecology

Faculty of Sciences, University of Novi Sad

Novi Sad, Serbia

E-mail: biometatandem@gmail.com 